\title{
Pola Pengembangan Pendidikan Tinggi Tekstil Di Indonesia Prospek dan Tantangannya
}

\author{
Oleh : Sunaryo
}

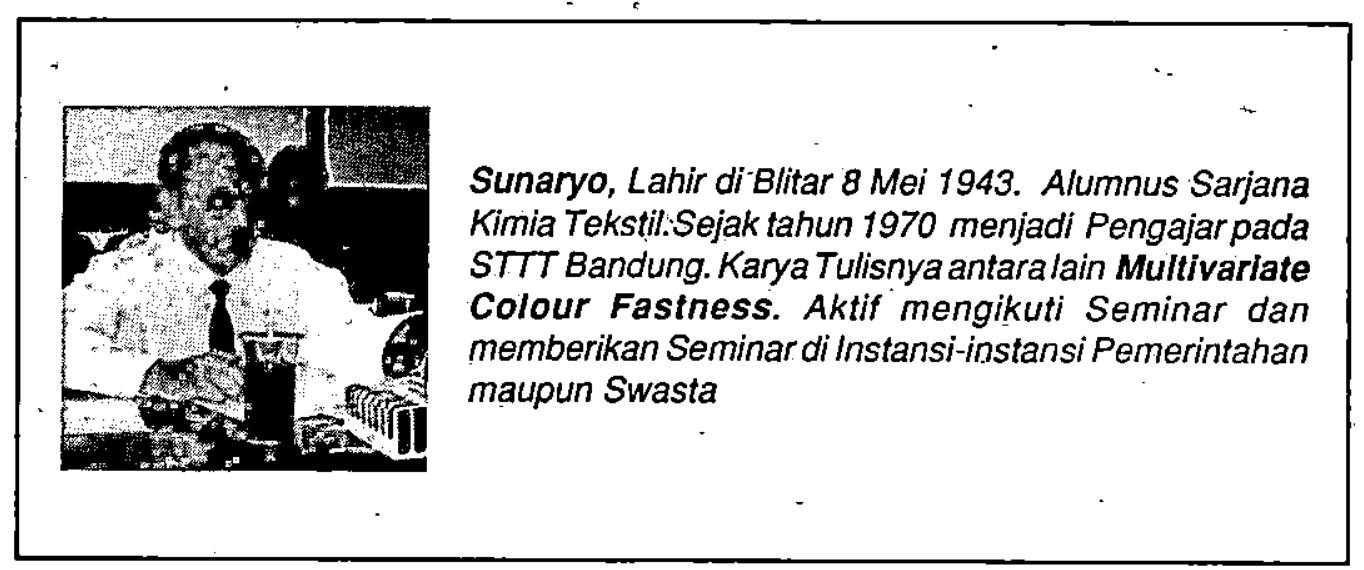

Pengantar

Perkembangan industri di Indonesia dewasa ini telah mencapai tingkat sedemikian sehingga negara yang sedang berkembang telah dapat dikatakan sebagai negara industri. Khusus mengenai industri tekstil, perkembangan tersebut dapat dilihat dari semakin banyaknya investasi di bidang tersebut dan juga semakin besamya ekspor tekstil dan produk tekstil serta kemampuannya dalam memenuhi konsumsi di dalam negeri.

Perkembangan yang sangat - menggembirakan tersebut terasa menjadi semu manakala dilihat dari sisi pendukung kemajuan industri itu sendiri karena industri tekstil di Indonesia ternyata baru mampu berlaku sebagai industri hilir sedang industri hulu dan pendukungnya masih -belum terjamah. Ketergantungannya terhadapluar negeri, terutama dalam hal bahan baku, mesin/peralatan produksi dan juga teknologinya masih cukup besar.

Sebagaimana disadari bersama $\mathbf{I n -}$ donesiamemiliki kemampuan-kemampuan baik dalam masalah sumber daya alam pendukung industri hulu maupun sumberdaya manusia pelaku industri. Namun demikian disadari pula bahwa Indonesia mempunyai kelemahan di dalam hal pemanfaatan daya alam dan sumberdaya manusia tersebut karena kurangnya penguasaan teknologi. Oleh karena itu sudah sewajamyalah apabila penguasaan teknologi tersebut menjadi fokus perhatian bagi kalangan pendidikan melalui penyelenggaraan pendidikan yang mampu menciptakan sumberdaya manusia yang tangguh dalam pola berfikir inovatif. Untuk itu pendidikan harus dikembangkan sedemikian sehingga mampu menjawab tantangan tersebut. 
Industri Tekstil dan Kelangsungan Hidupnya

Untuk dapat memajukan suatu industri perlu diperhatikan adanya tiga prasyarat, yaitu bahan baku, modal dan pemasaran. Tanpa bahan baku dan tanpa modal industri tidak mungkin dapat berjalan. Demikiänhalnya dengan masa Tah pemasaran, karena tidak adanya prospek untuk dapat memasarkan produknya, industri tersebut akan mati: Pemasaran ini dapat berjalan sebagaimana diharapkan apabila produk yang dipasarkan dapat memenuhi selera konsumen baik dari segi desain, mutu dan harga. Untuk dapat menghasilkan produk yang memenuhi selera konsumen, penggunaan teknologi yang sesuai akan sangat menunjang. Jika hal tersebut terpenuhi maka kelangsungan hidup industri akan tetap terjamin dan bahkan mungkin saja dikembangkan. Oleh karena itu selain ketiga pra-syarat di atas, maka demi kelangsungan hidup suatu industri, penguasaan teknologi merupakan pra-syarat yang perlu mendapat perhatian.

\section{A. Bahan Baku}

Sumber daya alam baik berupa hasil pertanian, barang tambang dan lainnya merupakan modal dasar yang dimiliki Indonesia dalam usaha pengembangan industrinya. Namun pada kenyataannya bahan mentah yang tersedia belum dimanfaatkan untuk diolah menjadi bahan baku. Kendala utama dalam masalah ini adalah lemahnya periguasaan ilmu dan teknologi untuk mengolahnya. Penguasaan ilmu dan teknologi yang mencakup pengetahuan dasar sintesa bahan, berbagai metoda pernrosesannya serta faktor-faktor yang menentukan dalam proses tersebut, seperti sifat dan karakteristik bahan, pengaruh berbagai perlakuan sertapengaruh lingkungan terhadap bahan tersebut masih sangat minim. Selain serat sebagai bahan baku, maka tidak kalah pentingnya untuk dikembangkan adalah industri-industri penunjang seperti industri zat wama, zat pembantu tekstil, mesin tekstil dan suku cadangnya. Demikian halnya dengan masalah diversifikasi produk yang tidak mungkin dikembangkan tanpa terlebih dahulu menguasai ilmu dan teknologi dari bahàn tersebut. Hal inilah yang menyebabkan mengapa ketergantungan Indonesia dari luar negeri masih cukup besar.

\section{B. Modal}

Modal untuk pengembangan industri dapat diperoleh baik dari dalam negeri maupun dari luarnegeri sepanjang stabilitas mantap dan ada kebijaksanaan pemerintah yang menunjang. Hanya saja pemanfaatan modal itu sendiri masih perlu dipertanyakan. Modal yang telah diperoleh terutama dari luar negeri yang selama ini masih banyak digunakan untuk pembelian peralatan atau mesin-mesin dari luar negeri sebaiknya mulai didorong untuk digunakan membantu peningkatan kemampuan dalam negeri untuk membuat barang modai. Untuk dapat membuat barang modal diperlukan penguasaan teknologi yangmenunjang. Jika keadaan ini dapat diatasi maka ketergantungan terhadap luar negeri akan semakin berkurang atau bahkan ditiadakan.

\section{Pemasaran}

Sebagaimana diketahui, tekstil dan produk tekstil telah merupakan komoditi ekspornon migas nomorsatu menggantikan kedudukan ekspor kayu. Yang menjadi pertanyaan adalah apakah ekspor TPT (Tekstil dan Produk Tekstil) tersebut mumi merupakan hasil kerja pemasar atau merupakan fasilitas dan kelonggaran yang 
telah diperoleh dari negara maju atau karena belum adanya pesaing yang tangguh ? Jika masalah kedua dan ketiga belum muncul maka masalah pertama belum mendapat perhatian. Akan tetapi pada kenyataannya masalah kedua dan ketiga justru telah muncul dalam era globalisasi sekarang ini. Oleh karena itu ketangguhan pemasar merupakan hal yang perlu memperoleh perhatian khusus. Tentu saja hal tersebut harus didukung oleh produk yang memenuhi selera konsumen. Untuk dapat memenuhi selera konsumen salah satu faktoryang perlu mendapat perhatian adalah teknologi yang digunakan dalam membuat produk tersebut.

\section{Penguasaan Teknologi}

Bagaimanapun tangguhnyapemasar, maka masalah yang bersangkut paut dengan produk itu sendiri merupakan faktorpenting yang dapat menentukan berhasil tidaknya produktersebutdipasarkan. AgarTPT dapat bersaing di luar negeri, maka produk tersebut harus dapat memenuhi selera konsumen. Untuk dapat merebutkonsumen produk tersebut harus mampu bersaing dalam hal mutu dan desain selain harga. Masalah peningkatan mutu dan penekanan harga tersebut oleh industri di luar negeri dipecahkan dengan otomatisasi proses produksi. Apabila produk kita hendak bersaing dengan produk luar negeri, maka pola produksi seperti itu mau tidak mau harus diterapkan. Keunggulan komparatif dalam murahnya tenaga kerja tidak lagi dapat diandalkan dalam membúat suatu produk menjadi lebih murah. Seringkali terjadi bahwa produk menjadi tidak murah, karena proses pembuatannya tidak efisien serta mutunya kurang baik. Di lain pihak dengan sistem otomatisasi yang teknologinya masih belum sepenuhnya dikuasai masih perlu diimpor baik dalam bentuk barang jadi untuk berproduksi maupun rckayasa teknologi pada umumnya masih tetap dirahasiakan.

\section{Pendidikan Tinggi Tekstil, Pengembangan dan Prospeknya}

Jika disimak dari hal yang telah diuraikandiatas, maka timbullah pertanyaan sampai sejauh mana pendidikan tinggi tekstildi Indonesia telah dipersiapkan untuk mengantisipasi 'masalah tersebut ? Sebagaimana diuraikan dimuka, pengembangan suatu industri tidak hanya terkait kepada penguasaan bahan baku, modal dan pemasaran saja, tétapi sumber daya manusia sebagai pelaku industri merupakan faktor yang tidak kalah pentingnya untuk mendapatkan perhatian. Karena hampir semua teknologi masih merupakan komoditi impor, maka dalam pengembangan industri, kini dilakukan lewat alih teknologi. Alih teknologi itu sendiri padakenyataannya harusmerupakan suatu pencurian atau perampasan, karena bagaimanapun juga tidak mungkin kesemuanya disampaikan secara menyeluruh dan terbuka. Alih teknologi yang paling bagus adalah dengan cara melihat, membaca dan mendengar dalam pengertian melihat apa yang tersembunyi, membaca apa yang tidak tertulis dan mendengar apa yang tidak berbunyi. Hal ini berarti harus dilakukan oleh orang yang ahli dalam bidang yang ditelitinya. Tenaga ahli semacam inilah yang masih kurang dihasilkan olehpendidikan tinggi terutama pendidikan tinggi tekstil.

\section{A. Kondisi Pendidikan Tinggi Tekstil Dewasa Ini}

Pendidikan tinggi tekstil di Indonesia 
pertama difokuskan kepada masalah penyediaan tenaga ahli tekstil guna menangani masalah manufakturing. Keahlian jenis tersebut sangat diperlukan dalam upayamempersiapkan industri tekstil sebagai substitusi impor.

Untuk memenuhi permintaan tenaga ahli bidang pengolahan temyata Sekolah Tinggi Teknik Tekstil di Bandung yang merupakan pelopor penyelenggaraan pendidikan tinggi di Indonesia sejak . 40 tahun yang lalu, terbatas kemampuannya sehingga tidak dapat memenuhi permintaan yang jumlahnya cukup besar. Oleh karenanya timbullah inisiatif dari berbagai fihak swasta untuk ikut berperan serta menangani masalah tersebut. Program dan jenjang yang telah diselenggarakannyapun telah beberapa kali mengalami perubahan menyesuaikan dengan peraturan yang berlaku. Pada waktu ini program yang diselenggarakan terdiri dari dua jalur yaitu Jalur keahlian Profesi dan Jalur Keahlian Akademik. Jenjang pada program profesi adalah Diploma 4 (D4) dan Diploma 3 (D3) sedang jenjang pada program akademik adalah Strata Satu (S1). Namun pada kenyataannya keduajalur tersebut menjadi kabur batas-batasnya karena baik Program Diploma maupun Program Strata, keduanya masih berfokus kepada masalah pengolahan denganskala penekanan yang agak berbeda. Jika dilihat dari tujuan penyelenggaraan pendidikannya, pada kedua jalur tersebut seharusnya terdapat perbedaan yang mendasar.

Program Diploma atau lazim dikenal dengan program keahlian profesi lebih ditekankkan untuk menghasilkan tenaga ahli untuk menangani masaläh pengolahan sedang program strata atau lazim dikenal dengan program keahlian akademik lcbih ditekankan untukmenghasilkan tenaga ahli bidang penelitian dan pengembangan serta pendidikan.

\section{B. Pengembangan Pendidikan Tinggi Tekstil di Masa Datang}

Hasil-hasil yang telah dicapai pada PJPT Pertama ini temyata menunjukkan bahwa industri tekstil tidak sekedar sebagai substitusi importetapi telah mampu menjadi primadona komoditi ekspor non migas. Hanya saja kemajuan yang telah dicapai tersebut masih dihadapkan pada hambatan sebagaimanadiuraikan di atas yaknilangkah tenaga ahli dalam penanganan masalah yang mendasar yaitu penguasaan ilmu dan teknologi untuk bahan baku dan pemasaran serta pengembangan teknologi.

Salah satu cara di dalam mengatasi masalah tersebut adalah dengan menyiapkan suatu program pendidikan tinggi tekstil yang mampu menjawab tantangan di atas.

Para penyelenggara pendidikan tinggi tekstil selain tetap menyelenggarakan pendidikan untuk menghasilkan tenaga ahli bidang pengolahan melalui Program Diploma 3 dan 4, harus sanggup mengadakan . perubahan yang mendasar untuk dapat menghasilkan tenaga ahli bidang akademik yang mampu melakukan penelitian sehingga dapat menjangkau masalah bahan baku, mesin dan pemasaran yang dilengkapi dengan keahlian bidang sains teknologi dan rekayasa. Tenaga ahli semacam ini sangat diperlukan dalam pengembangan industri tekstil yang diharapkan tetap dapat menjadi tulang punggung industri di Indonesia. Di luar negeri terdapat lembaga pendidikan yang menangani bidang tekstil tidak saja pada tingkat sarjana, tetapi bahkan sampai tingkat pasca-sarjana. . 


\section{Penutup}

Jika diharapkan industri tekstil tetap dapat menjadi tulang punggung penghasil devisa negara, maka industri tekstil harus menjangkau tidak saja industri hilir, tetapi juga industri hulu. Untuk mencapai tujuan tersebut maka sumber daya manusia yang keahliannya memadai pada bidang tekstil sebagai salah satu faktor penting perlu mendapatkan prioritas penangannya. Lembaga pendidikan tinggi tekstil sebagai penghasil tenaga ahli tekstil harus mampu dan sanggup mengadakan perubahan yang mendasar sehingga program yang disajikan dapatmenghasilkan tenaga ahli tekstil untuk bidang rekayasa, penelitian dan pengembangan serta pendidikan. 